\title{
MODEL INTEGRASI DALAM RESOURCES-BASED VIEW UNTUK PENERAPAN STRATEGI BERSAING DAN PENCAPAIAN KINERJA USAHA
}

\author{
I Nengah Suardhika \\ suardhika@yahoo.co.id \\ STIE Triatma Mulya Bali
}

\begin{abstract}
This study develops a model of integration which refers to the RBV of the firm to understand the control of strategic resources and entrepreneurial orientation as a basis for aligning competitive strategy in a dynamic environment and improved business performance. The results of SEM analysis of survey data as many as 153 export-oriented SMEs in Bali proved that the combination of strategic resources and entrepreneurial orientation is the underlying strategic instrument to implement the competitive strategy of SMEs, so as to improve or enhance its competitive position. A better competitive position of SMEs obtained, being able to align the dynamics of the business environment faced, and delivering SME to achieve improved business performance. If SMEs do not implement competitive strategy is based on the integration of strategic resources and entrepreneurial orientation, the dynamic environment encountered can inhibit or decrease the achievement of business performance.
\end{abstract}

Keywords: Resource-based view, competitive strategy, business performance

\begin{abstract}
ABSTRAK
Penelitian ini mengembangkan model integrasi yang mengacu pada $R B V$ of the firm untuk memahami penguasaan sumber daya strategis dan orientasi kewirausahaan sebagai landasan strategi bersaing dalam menyelaraskan dinamika lingkungan dan peningkatan kinerja usaha. Hasil analisis SEM dari data survei sebanyak 153 UKM yang berorientasi ekspor di Bali membuktikan bahwa kombinasi sumber daya strategis dan orientasi kewirausahaan merupakan instrumen strategis yang mendasari UKM untuk menerapkan strategi bersaing, sehingga mampu memperbaiki atau meningkatkan posisi kompetitifnya. Posisi kompetitif yang lebih baik diperoleh UKM, karena mampu menyelaraskan dinamika lingkungan bisnis yang dihadapi, dan menghantarkan UKM untuk meraih peningkatan kinerja usaha. Apabila UKM tidak menerapkan strategi bersaing yang dilandasi pengintegrasian sumber daya strategis dan orientasi kewirausahaan, maka dinamika lingkungan yang dihadapi dapat menghambat atau menurunkan pencapaian kinerja usaha.
\end{abstract}

Kata kunci: Resource-based view, strategi bersaing, kinerja usaha

\section{PENDAHULUAN}

Pemberdayaan usaha kecil dan menengah (UKM) merupakan hal yang krusial bagi peningkatan perekonomian Indonesia, karena sampai saat ini UKM telah banyak memberikan kontribusi penting bagi pertumbuhan ekonomi negara, baik penyediaan lapangan kerja, kesempatan kerja, peningkatan pendapatan masyarakat dan ekspor non-migas (Hakim, 2007). Upaya-upaya untuk memberdayakan UKM menjadi semakin kritis terkait dengan perubahan lingkungan bisnis global secara dramatis, sehingga UKM dituntut untuk meraih keunggulan kompetitif mampu mempertahankan eksistensinya (Anatan dan Ellitan, 2009). Sementara itu, telah disadari daya saing dari UKM di Indonesia umumnya masih relatif rendah serta rentan terhadap perubahan lingkungan bisnis yang semakin turbulen dan tidak pasti. Kondisi ini berdampak rendahnya produktivitas yang dihasilkan dan tidak sedikit UKM mengalami kegagalan usaha (Riyanti, 2003). Hal ini disebabkan kekurangmampuan UKM ber- 
adaptasi dan responsif terhadap lingkungan bisnis yang dihadapi karena minimnya kemampuan internal yang dimiliki (Scarborough dan Zimmerer, 2008).

Pengelolaan usaha berbasis sumber daya (resources-based) merupakan salah satu alternatif solusi bagi UKM, karena melalui pengelolaan tersebut mampu menciptakan kompetensi khusus dan memberikan pilihan strategis untuk meraih keunggulan kompetitif berkelanjutan (Barney, 2001; Grant, 2010). Untuk meraih keunggulan kompetitif berkelanjutan tidak terlepas dari resource based-view (RBV) yang mengarahkan manajemen perusahaan untuk mengidentifikasi, menguasai, dan mengembangkan sumber daya strategis dalam rangka menghasilkan kinerja secara optimal (Barney et al., 2004).

Sumber daya strategis merupakan sekumpulan aset dan kapabilitas yang dijadikan kompetensi inti bagi perusahaan dalam menciptakan keunggulan kompetitif (Collis dan Montgomery, 2004). Selanjutnya, Aaker (2001) berpendapat bahwa sumber daya strategis merupakan instrumen strategik yang mendasar untuk menghasilkan keunggulan kompetitif bagi perusahaan, apabila memberikan makna bagi operasi dan kompetisi, serta dijadikan landasan dalam pemilihan strategi. Dengan demikian, proses pengembangan, pemeliharaan, serta pengendalian sumber daya strategis merupakan upaya penting dilakukan dari waktu ke waktu, dan hakikatnya sebagai pondasi kuat untuk meraih keunggulan kompetitif berkelanjutan, serta menciptakan kinerja superior bagi perusahaan (Ferdinand, 2006).

Beberapa literatur manajemen stratejik menunjukkan bahwa kesesuaian strategi dengan sumber daya yang dimiliki merupakan awal penting bagi perbaikan kinerja suatu perusahaan. Hal ini selaras dengan pandangan Porter, 1996; Grant, 2010; serta Daniel dan Rocío, 2007 bahwa sumber daya strategis yang dikuasai perusahaan digunakan sebagai dasar formulasi dan implementasi strategi untuk mewujudkan kinerja usaha yang optimal. Selain itu, Barney (2001) menambahkan bahwa kelangsungan atau keunggulan perusahaan tergantung pada sumber daya yang dimiliki, serta strategi apa yang dipilih untuk memberdayakan sumber daya tersebut, sehingga mampu merespon dengan baik peluang dan tantangan dari lingkungan bisnis yang dihadapi. Konsepsi ini dapat dibuktikan secara empiris oleh Edelman et al. (2002) bahwa sumber daya maupun strategi secara individu tidak mampu menjelaskan kinerja perusahaan-perusahaan kecil dalam industri yang mempunyai sedikit daya tarik di Amerika Serikat. Walaupun demikian, hanya implementasi strategi yang cocok dengan profil-profil sumber dayanya mampu meningkatkan kinerja perusahaan (Edelman et al., 2002).

UKM pada umumnya memiliki keterbatasan dalam pengendalian sumber daya strategis, serta level penelitian pasar dan perencanaan formal yang masih rendah. Kondisi ini mendorong pentingnya investasi untuk mengembangkan sumber daya strategis agar sejalan dengan penerapan strategi-strategi dalam rangka penciptaan keunggulan bersaing serta menghasilkan peningkatan kinerja perusahaan (Barney et al., 2004). Selain itu, Aaker (2001) menyampaikan bahwa keunggulan kompetitif dapat diperoleh dari sumber daya strategis yang diciptakan atau diakuisisi, dipelihara dan dikembangkan oleh perusahaan sebagai basis pemilihan strategi bersaing, sehingga nantinya dapat berperan sebagai "strategic weapon" untuk manuver kompetisi pasar yang dihadapinya. Dengan demikian, keberhasilan UKM dalam meningkatkan kinerja usaha tidak semata diperoleh dari penguasaan, pengendalian, dan pengembangan sumber daya strategis. Penerapan strategi bersaing yang sesuai dengan sumber daya strategis, mampu memberikan keunggulan berkompetisi, serta mengarahkan UKM untuk meraih kinerja usaha yang lebih baik dalam jangka panjang.

Tindakan kewirausahaan telah diyakini dalam RBV sebagai kapabilitas tam- 
bahan yang dapat memberikan keragaman dan nilai bagi perusahaan, serta memberikan kontribusi penting terciptanya keunggulan kompetitif perusahaan (Alvarez dan Busenitz, 2001; Carmeli, 2004). Tindakan kewirausahaan dalam penelitian ini diwujudkan sebagai orientasi kewirausahaan (entrepreneurial orientation) merupakan perilaku perusahaan yang tercermin dari perilaku pemilik atau pengelola dalam proses pengambilan keputusan strategis melalui keinovasian, berani mengambil risiko, dan proaktivitas (Green et al., 2008; Hermann et al., 2010). Konsepsi ini terkait dengan strategi entrepreneurial yang lebih memfokuskan pada proses entrepreneurial, dan bukan aktor di belakangnya (Wiklund dan Dean, 2005). Inti dari konsepsi ini, perusahaan yang berorientasi wirausaha selalu melakukan inovasi produk dan proses secara konsisten, berani mengambil risiko bisnis, serta bersikap proaktif dalam berkompetisi. Covin et al. (2006) menambahkan bahwa perusahaan yang berorientasi wirausaha selalu sukses untuk menemukan peluang-peluang baru dalam aktivitas bisnis nya, serta memperkuat posisi kompetitifnya di pasar.

Foss et al. (2008) menekankan bahwa pelaksanaan dan pengembangan kewirausahaan berperan penting bagi perusahaan kecil dan menengah dalam aktivitasaktivitas strategisnya. Hal ini mengindikasikan, atribut-atribut personal dari pemilik atau pengelola yang membentuk orientasi kewirausahaan berperan penting dalam perumusan dan pelaksanaan strategi usaha untuk memperbaiki atau meningkatkan posisi kompetitifnya. Demikian pula Ferreira dan Azevedo (2007), menyatakan bahwa perusahaan yang berorientasi wirausaha dapat berpotensi menghasilkan variasivariasi kinerja yang lebih menguntungkan dalam jangka panjang, bila diintegrasikan dengan strategi-strateginya. Penjelasan tersebut dapat dimaknai, perusahaan yang melaksanakan orientasi kewirausahaan memfokuskan aktivitas usahanya untuk menciptakan perubahan dengan cara memanfaatkan peluang dari dinamika lingkungan bisnis yang dihadapi. Selanjutnya, menciptakan keuntungan dengan cara mengidentifikasi peluang dalam lingkungan bisnis dan mengembangkan keunggulan kompetitif melalui penerapan strategistrategi untuk memanfaatkannya (Ireland et al., 2001). Mengingat pentingnya pelaksanaan orientasi kewirausahaan dalam meraih keunggulan kompetitif dan kesuksesan usaha, maka UKM perlu mengembangkan orientasi kewirausahaan dalam aktivitasaktivitas usahanya, serta dijadikan landasan perumusan dan penerapan strategi dalam berkompetisi.

Keunggulan kompetitif perusahaan dalam era globalisasi saat ini juga ditentukan oleh faktor lingkungan bisnis (eksternal). Lingkungan bisnis dipandang sebagai kondisi dinamis yang sulit diramalkan perubahannya, serta dapat menciptakan peluang dan tantangan bagi perusahaan (Miles et al., 2000), serta sebagai sumber informasi dan wahana penyedia sumber daya (Hitt et al., 2011). Berkaitan dengan hal tersebut, kelangsungan hidup dan keberhasilan perusahaan tergantung pada kemampuan memantau dan beradaptasi terhadap lingkungan bisnisnya, sehingga dapat memandu penerapan strategi bisnis untuk mencapai tujuan usaha secara efektif (Porter, 1996; O'Regan et al., 2008).

Lingkungan bisnis yang diteliti fokus pada dinamika lingkungan, dikonsepsikan sebagai lingkungan yang berubah cepat dan diskontinyu pada permintaan pasar, pesaing, teknologi dan regulasi, sehingga informasi seringkali tidak akurat atau tidak tersedia (Anand dan Ward, 2004), serta diidentifikasi adanya ketidakpastian lingkungan dan intensitas persaingan yang tinggi (Hashim et al., 2001). Dalam menghadapi dinamika lingkungan tersebut mendorong perusahaan berperilaku entrepreneurial, melalui pelaksanaan inovasi dan keberanian mengambil risiko dalam aktivitas bisnis (Miles et al., 2000; Covin et al., 2006).

Banyak peneliti telah mendokumentasikan dengan baik keterkaitan lingkungan 
bisnis, strategi, dan kinerja perusahaan. Kajian tersebut mendukung konsep contingency yang menekankan penyelarasan strategi dengan lingkungan bisnis sebagai penentu kelangsungan hidup atau kinerja perusahaan (Daniel dan Rocío, 2007). Posisi unggul dalam persaingan dapat diwujudkan oleh perusahaan apabila mampu mencocokkan sumber daya yang dikuasai dengan peluang-peluang dari lingkungan eksternalnya atau menggunakan untuk mengurangi dampak ancaman melalui penerapan strategi bisnis (Hitt et al., 2011). Hal ini sejalan dengan pendapat Miles et al. (2000) bahwa analisis dan diagnosis sumber daya dengan lingkungan eksternal perusahaan harus dilakukan secara sinergis, serta dijadikan input dalam penyusunan strategi perusahaan untuk menciptakan kinerja yang ber kesinambungan. Sementara itu, lingkungan bisnis eksternal dapat memberikan dampak langsung terhadap kinerja bisnis tanpa melihat pilihan strategi-strategi yang dijalankan perusahaan (Porter, 1996; O'Regan et al., 2008). Ini berarti, lingkungan bisnis dapat dapat memberikan dampak langsung maupun tak langsung kinerja perusahaan.

Hak-hal di atas menimbulkan motivasi untuk mengkaji secara empiris terkait dengan isu-isu UKM dalam meraih keunggulan kompetitif. Kajian ini dilakukan dengan mengembangkan suatu model penelitian berdasarkan RBV of The Firm yang mengintegrasikan sumber daya strategis dan orientasi kewirausahaan sebagai dasar penerapan strategi bersaing untuk menghadapi dinamika lingkungan bisnis, sehingga dapat memperbaiki atau meningkatkan kinerja usaha. Hal sesuai dengan pandangan para ahli dalam bidang manajemen stratejik bahwa menciptakan keunggulan kompetitif perusahaan sangat tergantung pada kesesuaian antara kapabilitas internal dan perubahan kondisi eksternal yang dihadapi (Barney et al., 2004; Alejandro et al., 2008; Anatan dan Ellitan, 2009).
Penelitian ini bertujuan untuk menganalisis, menguji dan menjelaskan: (1) pengaruh sumber daya strategis, orientasi kewirausahaan dan dinamika lingkungan terhadap strategi bersaing; (2) pengaruh sumber daya strategis, orientasi kewirausahaan, dinamika lingkungan, serta strategi bersaing terhadap kinerja usaha; dan (3) pengaruh sumber daya strategis, orientasi kewirausahaan dan dinamika lingkungan terhadap kinerja usaha melalui mediasi strategi bersaing.

\section{TINJAUAN TEORETIS}

\section{Pengaruh sumberdaya strategis terhadap strategi bersaing}

UKM di Indonesia pada umumnya menghadapai keterbatasan-keterbatasan dalam aktivitas usahanya, seperti kekurangan modal, kesulitan memperoleh bahan baku, kekurangan akses informasi bisnis, kesulitan dalam pemasaran dan distribusi, serta rendahnya penguasaan teknologi yang diidentifikasi terbatasnya kepemilikan dan penguasaan sumber daya strategis. Selain itu, perusahaan kecil umumnya dimiliki secara pribadi mungkin menggunakan strategi sub-optimal yang berdasarkan preseden nilai, kepercayaan dan bias, sehingga menghasilkan keterbatasan pemantauan aksi manajerial (Daniel dan Rocio, 2007). Keadaan ini mendorong pentingnya investasi untuk mengembangkan penguasaan sumber daya agar sejalan dengan penerapan strategi dalam rangka meningkatkan posisi bersaing untuk mewujudkan pencapaian kinerja usaha secara optimal (Barney et al., 2004). Selain itu, Barney (2001) menyatakan bahwa pengintegrasian, pengeksploitasian dan transformasi sumberdaya strategis ke dalam strategi bersaing yang mampu merespon ancaman dan peluang dari lingkungan bisnisnya, cenderung menghasilkan posisi unggul dalam persaingan dan mampu meningkatkan kinerja usahanya.

Penggunaan sumberdaya, baik tangible maupun intangible merupakan kompetensi utama untuk memformulasikan dan meng- 
implementasikan strategi (Grant, 2010). Selaras yang dinyatakan Barney (2001), kelangsungan atau keunggulan perusahaan tergantung pada sumberdaya dan kapabilitas manajerial yang dimiliki, serta strategi apa yang dipilih dalam memberdayakan sumberdaya tersebut untuk merespon ancaman dan peluang dari lingkungan bisnisnya. Dengan demikian, penguasaan, pengelolaan dan pengembangan sumberdaya strategis yang dimiliki perusahaan dapat digunakan untuk merumuskan dan menentukan strategi bersaing dengan tepat dalam rangka meningkatkan kinerja usaha.

Penelitian yang dilakukan Edelman et al. (2002) memberikan hasil yang mendukung pandangan sebelumnya bahwa sumberdaya perusahaan memberikan kontribusi yang positif terhadap strategi yang dilaksanakannya. Lebih lanjut, Edelman et al. (2002) menyampaikan bahwa kekuatan sumber daya perusahaan yang dibangun dan dikembangkan berdasarkan sumber daya manusia dan organisasi, mendorong pelaksanaan strategi kualitas/pelanggan maupun strategi inovasi, secara statistik sumber daya manusia berpengaruh positif terhadap strategi kualitaspelanggan maupun strategi inovasi, sedangkan sumber daya organisasi berpengaruh positif terhadap strategi kualitas.

Hasil empiris lainnya, Hakim (2007) yang mengkaji sumber daya dari sudut kapabilitas organisasi ditemukan dapat mendukung peningkatan penerapan strategi bisnis. Hal yang sama dilaporkan Nurhajati (2004), bahwa faktor internal berpengaruh terhadap strategi usaha. Hasil temuan ini mengindikasikan faktor internal memiliki peranan yang besar dalam penentuan strategi usaha.

Rivard et al. (2005) yang mengkaji efek dukungan IT bagi aset perusahaan terhadap strategi bisnis pada 96 usaha kecil dan menengah (SME) di Propinsi Quebec, Kanada, menemukan hubungan positif yang signifikan antara dukungan IT untuk aset perusahaan terhadap strategi bisnis. Ini menunjukkan semakin besar dukungan IT yang disediakan untuk meningkatkan keberadaan sumber daya atau mengembang kan salah satunya, perusahaan akan memiliki kemampuan besar dan melengkapi sumber daya yang lebih baik untuk memenuhi peningkatan ketersediaan pemro sesan informasi untuk suatu strategi bisnis, sehingga memberikan efek (kegunaan) yang besar terhadap kinerja perusahaan. Dengan demikian, dapat dirumuskan hipotesis penelitian :

$\mathrm{H}_{1 \mathrm{a}}$ : Sumberdaya strategis berpengaruh positif terhadap strategi bersaing.

\section{Pengaruh orientasi kewirausahaan terha- dap strategi bersaing}

Orientasi kewirausahaan dianggap sebagai sumberdaya tambahan perusahan (Ferreira dan Azevedo, 2007) atau kapabilitas organisasi yang menunjukkan proses kewirausahaan dan bagaimana aktivitas usaha mampu dijalankan (Wiklund dan Dean, 1996). Selain itu, orientasi kewirausahaan merupakan kunci penggerak transformasi organisasi dan strategi melalui kombinasi sumberdaya strategis yang dimiliki perusahaan (Ireland dan Webb, 2007).

Pemanfaatan peluang entrepreneurial mendukung upaya perusahaan untuk menghasilkan keunggulan kompetitif dan menciptakan keuntungan. Namun, banyak perusahaan gagal untuk memotivasi orang dalam cara-cara mereka untuk mengejar peluang entrepreneurial, sehingga kurang berperan sebagai daya saing perusahaan (Avlonitis dan Salavou, 2007). Perusahaan entrepreneurial cenderung mampu mengidentifikasi dan memanfaatkan peluang untuk menciptakan atau menentukan keunggulan bersaing yang hanya bersifat sementara. Ini terjadi, karena perusahaan entrepreneurial tidak mampu menyelaraskan strategi berbasis sumberdaya yang diterapkan untuk mengeksploitasi peluang, sehingga sulit untuk mempertahankan keunggulan kompetitif yang dikembangkannya (Ireland et al., 2003). Oleh karena itu, 
perilaku pencarian peluang melalui orientasi kewirausahaan perlu diintegrasikan melalui penerapan strategi bersaing untuk menghasilkan keunggulan kompetitif dan menciptakan keuntungan (Ireland dan Webb, 2007).

Kajian empiris yang dilakukan Suci (2008) mendukung keterkaitan orientasi kewirausahaan dengan penerapan strategi bisnis. Lebih lanjut Suci (2008) melaporkan bahwa peningkatan pelaksanaan orientasi kewirausahaan mampu meningkatkan ketepatan strategi bisnis pada 314 pengerajin bordir di Jawa Timur. Sejalan dengan temuan Suci (2008), Hakim (2007) menyampaikan bahwa kemampuan kewirausahaan yang dimiliki manajer koperasi dapat meningkatkan penerapan strategi bisnis. Sebaliknya, Nurhajati (2004) menemukan bahwa entrepreneurial skill yang dimiliki oleh pengelola usaha kecil tidak mendorong penerapan strategi dalam aktivitasnya. Temuan ini mengindikasikan, usaha kecil yang diteliti sangat jarang menerapkan strategi secara formal, namun demikian entrepreneurial skill yang dimiliki oleh pengelola usaha kecil sudah dianggap mampu menggerakkan aktivitas operasi untuk mencapai kesuksesan usaha.

Bagaimanapun, perusahaan yang berorientasi wirausaha berpotensi menghasilkan variasi kinerja yang lebih menguntungkan dalam jangka panjang, melalui integrasi dengan strateginya (Covin et al., 2006). Oleh karena itu, perusahaan yang berorientasi wirausaha akan mampu mengidentifikasi peluang usaha dengan baik, yang selanjutnya dikembangkan menjadi daya saing melalui penerapan strategi untuk memanfaatkan peluang tersebut. Dengan demikian, dapat dirumuskan hipotesis penelitian :

$\mathrm{H}_{1 b}$ : Orientasi kewirausahaan berpengaruh positif terhadap strategi bersaing.

\section{Pengaruh dinamika lingkungan terhadap penyesuaian strategi bersaing}

Lingkungan usaha dapat dipandang sebagai kekuatan yang mampu mempe- ngaruhi perusahaan baik secara langsung maupun tak langsung. Dinamika lingkungan dikatakan sebagai lingkungan yang berubah dengan cepat dan diskontinyu, sehingga informasi seringkali tidak akurat atau tidak tersedia (Anand dan Ward, 2004). Oleh karena itu, lingkungan usaha perlu diamati secara cermat guna mengantisipasi setiap perubahannya, serta proaktif mencari pola untuk memahami lingkungan usahanya untuk digunakan sebagai bahan pertimbangan dalam pengambilan keputusan bisnis (Green et al., 2008).

Penyelarasan strategi dengan lingkungan bisnis menentukan kelangsungan hidup dan kinerja perusahaan (Alejandro et al., 2008). Perusahaan yang mampu menyelaraskan strategi atau perusahaan menunjukkan tingkat adaptif dan fleksibilitas yang tinggi dengan lingkungan bisnisnya serta memperlihatkan kinerja yang lebih baik dibandingkan dengan perusahaan yang kurang berhasil menyelaraskan strategi dengan lingkungan bisnisnya (Anand dan Ward, 2004; Grant, 2010). Selanjutnya, Hitt et al. (2011) menyampaikan bahwa strategi bisnis memiliki hubungan yang signifikan dengan sejumlah dimensi dari lingkungan, sehingga dapat memberikan dampak positif terhadap kinerja perusahaan.

Kajian-kajian terdahulu telah menemukan bahwa lingkungan bisnis memiliki pengaruh langsung terhadap strategis bisnis (Suci, 2008; Tan dan Tan, 2005). Selain itu, Miles et al. (2000) menyampaikan bahwa organisasi dengan pendekatan dinamis dalam pengembangan strategi dapat mencapai kinerja unggul dalam seluruh lingkungan kompetitif. Pada kajian lainnya, Desarbo et al. (2005) menemukan bahwa strategi yang digunakan tergantung pada tipe dan level ketidakpastian lingkungan. Tingginya ketidakpastian lingkungan dan intensitas persaingan dalam lingkungan dinamis mendorong perusahaan untuk meningkatkan penyesuaian strategi bisnisnya agar dapat mencapai kinerja usaha yang diharapkan (Hashim et al., 2001). 
Sedangkan, O'Regan et al. (2008) melaporkan bahwa lingkungan persaingan yang kompetitif mampu dihadapi perusahaan kecil dengan menerapkan berbagai gaya strategi. Berdasarkan uraian di atas, dirumuskan hipotesis penelitian:

$\mathrm{H}_{1 \mathrm{c}}$ : Dinamika lingkungan berpengaruh positif terhadap penyesuaian strategi bersaing.

\section{Pengaruh sumberdaya strategis terhadap kinerja usaha}

Sumberdaya Strategis, Orientasi Kewirausahaan, Dinamika Lingkungan, dan Strategi Bersaing Serta Kinerja Usaha Keunggulan kompetitif dapat diwujudkan melalui optimalisasi pemanfaatan sumber daya strategis yang dikendalikan perusahaan. Tidak ada satupun perusahaan mempunyai kekuatan dan kelemahan yang sama, karena kompetensi inti merupakan pembeda penting untuk diidentifikasi dan dikelola (Collis dan Montgomery, 2004). Perusahaan yang mampu melakukan identifikasi sumber daya berdasarkan kelemahan atau kekuatan yang dimiliki, mampu membuat skala prioritas dan memilih sumber daya mana yang dapat dioptimalkan untuk menghasilkan produktivitas dan efisiensi dalam rangka mencapai keberhasilan usaha (Carmeli, 2004).

Perusahaan yang memiliki sumberdaya unggul, berpotensi dapat merespons ancaman dan peluang dengan baik sehingga dapat bertahan dan berkembang (Barney et al., 2004). Sebaliknya, perusahaan memiliki sumber daya yang tidak unggul, kemungkinan besar akan mengalami kesulitan dalam merespons ancaman dan peluang tersebut, sehingga berdampak pada kemerosotan dan kehancuran. Hitt et al. (2011) menambahkan bahwa keputusan yang dibuat para manajer berdasarkan sumber daya, kapabilitas dan kompetensi inti memiliki pengaruh yang signifikan terhadap kemampuan perusahaan untuk mengembangkan daya saingnya dan menghasilkan laba di atas rerata.
DeSarbo et al. (2007) melaporkan hasil kajiannnya bahwa kapabilitas yang terkait dengan pasar, kapabilitas teknologi, kapabilitas pemasaran, dan kapabilitas teknologi informasi mampu meningkatkan profitabilitas pada 216 perusahaan di Amerika Serikat. Temuan ini mengimplikasikan bahwa kapabilitas yang dimiliki perusahaan dapat membantu dalam pencapaian keunggulan kompetitif yang pada akhirnya menghasilkan profitabilitas perusahaan. Selain itu, Nurhajati (2004) menyampaikan hasil temuannya bahwa sumber daya perusahaan yang dicerminkan dalam faktor internal berpengaruh positif secara signifikan terhadap kinerja usaha.

Hasil yang sama juga diperoleh Chmielewski dan Paladino (2007), Ferreira dan Azevedo (2007), Rivard et al. (2005), dan Hakim (2007) bahwa pada hakekatnya sumber daya yang dimiliki dan dikelola dengan baik oleh perusahaan dapat meningkatkan kinerja perusahaan. Pada kajian lainnya, atribut-atribut sumber daya yang bernilai, langka dan tidak dapat digantikan ditemukan menjadi pengendali kinerja peru sahaan yang signifikan, serta merupakan atribut penting bagi kemampuan internasional (Ainuddin, 2007). Dengan demikian, dapat dirumuskan hipotesis penelitian:

$\mathrm{H}_{2 \mathrm{a}}$ : Sumberdaya strategis berpengaruh positif terhadap kinerja usaha.

Pengaruh orientasi kewirausahaan terhadap kinerja usaha.

Telah disampaikan dari berbagai kajian teoritis maupun empiris bahwa orientasi kewirausahaan (entrepreneurial orientation) mampu memberikan dampak yang besar terhadap kinerja usaha (Yang, 2007; Green et al., 2008). Covin et al. (2006) mengidentifikasi inisiatif perusahaan terkait dengan keinovasian, keberanian mengambil resiko, dan proaktif dengan menangkap aspek kewirausahaan secara spesifik baik pada gaya pengambilan keputusan, metode, maupun praktik dalam kegiatan operasi perusahaan (Wiklund dan Shepherd, 2005) 
sehingga dapat menimbulkan peningkatan kinerja usaha (Yang, 2007).

Hasil temuan yang dilaporkan Vitale et al. (2003), Suci (2008) menunjukkan orientasi kewirausahaan (EO) memiliki hubungan positif dan signifikan terhadap kinerja bisnis. Selain itu, Lee dan Tsang (2001) menyatakan bahwa kemampuan kewirausahaan yang tercermin dari perlaku pengelola sebagai determinan penting untuk meningkatkan pertumbuhan usaha atau kinerja usaha (Hakim, 2007). Sementara, Kaya dan Agca (2006) melaporkan temuannya bahwa inovativeness maupun proactiveness memiliki hubungan positif terhadap kinerja perusahaan.

Penelitian yang dilakukan Avlonitis dan Salavou (2007) yang mengkaji hubungan orientasi kewirausahaan (EO) dengan kinerja untuk mengidentifikasi profil EO dari SME's guna menunjukkan variasi dalam keinovasian produk pada potensi kinerja yang berbeda. Berdasarkan hasil temuannya dinyatakan bahwa orientasi proaktif dan pengambilan resiko dari entrepreneur aktif menunjukkan inovasi produk yang lebih unik bagi pasar dan menghasilkan kinerja lebih tinggi. Dengan demikian, dapat dirumuskan hipotesis penelitian :

$\mathrm{H}_{2 \mathrm{~b}}$ : Orientasi kewirausahaan berpengaruh positif terhadap kinerja usaha.

\section{Pengaruh dinamika lingkungan terhadap kinerja usaha.}

Kelangsungan hidup atau keberhasilan perusahaan ditentukan oleh karakteristik lingkungan dimana perusahaan itu beroperasi (Wiklund dan Shepherd, 2005). Hal ini mengindikasikan bahwa perubahan lingkungan bisnis mampu memberikan dampak secara langsung terhadap hasil yang dicapai perusahaan tanpa melihat pilihan strategi yang dijalankannya. Kondisi ini sesuai dengan hasil kajian Spanos (2001) bahwa lingkungan bisnis secara independen mampu mempengaruhi kinerja suatu perusahaan.
Rivard et al. (2005) dalam kajiannya menemukan hasil yang berbeda pada efek langsung lingkungan industri terhadap kinerja perusahaan, dimana perubahan yang terjadi dalam lingkungan industri dapat menghambat pencapaian kinerja pemasaran, namun tidak memberikan dampak terhadap profitabilitas usaha. Temuan ini mengindikasikan lingkungan hostility yang meningkat dapat menghambat pencapaian kinerja pemasaran, tetapi peningkatan lingkungan hostility tersebut mendorong usaha kecil dan menengah (SME's) mencari dan memanfaatkan peluang usaha secara intens sehingga mampu meningkatkan profitabilitas yang merupakan fokus pencapaian usahanya. Sedangkan, dalam kajian empiris Nurhajati (2004) ditemukan hanya indikator pembeli dari faktor eksternal yang memberikan kontribusi positif terhadap kinerja usaha.

Lain halnya kajian yang dilakukan Suci (2008) dan Hakim (2007) menemukan lingkungan bisnis eksternal tidak memberikan dampak secara langsung terhadap kinerja perusahaan. Temuan ini dapat memberikan implikasi bahwa perusahaan dapat berhasil dalam beberapa lingkungan bersaing. Sementara itu, Anand dan Ward (2004) menemukan bahwa dinamika lingkungan yang didasarkan ketidakpastian dan volatilitas lingkungan merupakan unsur moderasi antara skala dan mobilitas usaha terhadap kinerja usaha.

Bagaimanapun, kedinamisan lingkungan merupakan lingkungan yang berubah cepat dan diskontinyu pada permintaan pasar, pesaing, teknologi dan regulasi (Anand dan Ward, 2004), cenderung memberikan dampak ketidakpastian dan intensitas persaingan yang sangat tinggi sehingga akan dapat menghambat hasil yang dicapai perusahaan. Dengan demikian, dapat dirumuskan hipotesis penelitian:

$\mathrm{H}_{2 \mathrm{c}}$ : Dinamika lingkungan berpengaruh negatif terhadap kinerja usaha. 


\section{Pengaruh penerapan strategi bersaing terhadap kinerja usaha}

Dalam konteks bisnis, strategi-strategi dilaksanakan berdasarkan operasi perusahaan dari waktu ke waktu merupakan refleksi keputusan kunci yang dibuat sesuai dengan pengalokasian dan pengelolaan sumber daya yang dimiliki serta penyelarasan lingkungan bisnis yang dihadapi (DeSarbo et al., 2005). Ini mengindikasikan peran adaptif perusahaan sepanjang waktu, dapat mempengaruhi perubahan perilaku strategik, meningkatkan kompetisi, dan mendorong keselarasan perusahaan dalam lingkungannya. Adaptasi yang dilakukan merupakan cerminan tindakan pemilik atau pengelola usaha dalam memproses informasi yang datang dari lingkungan bisnisnya (eksternal dan internal) dan melalui penyesuaian secara cepat untuk umpan balik (Green et al., 2008).

Pada dasarnya setiap perusahaan memiliki strategi untuk menjalankan aktivitas usahanya, terlepas strategi tersebut dilaksanakan dalam bentuk formal maupun informal. Perlu diketahui dalam mengkaji strategi bisnis, strategi yang diterapkan di setiap perusahaan/industri memiliki perbedaan bahkan antar situasi dan kondisi yang dihadapi. Upaya yang dilakukan perusahaan untuk mengungguli para pesaing dapat dilakukan dengan menerapkan strategi bersaing. Penerapan strategi bersaing ini mengarahkan perusahaan untuk memfokuskan pada posisi kompetitifnya dalam industri, melalui strategi overall cost leaders, differentiations dan focus (Porter, 1996; Spanos, 2001). Dengan memperoleh posisi kompetitif yang lebih baik melalui penerapan strategi bersaing, perusahaan mampu meningkatkan kinerja usahanya.

Pernyataan di atas sesuai dengan hasil temuan Miles et al. (2000) yang mengkaji keterkaitan struktur perusahaan, gaya strategi dan praktek bisnis dengan kinerja perusahaan kecil baik pada lingkungan yang stabil maupun dinamis di Amerika Serikat. Miles et al. (2000) melaporkan bahwa strategi yang diterapkan dapat mendorong peningkatan kinerja perusahaan kecil dan yang paling kuat dibandingkan dengan faktor-faktor lainnya. Selain itu, hasil kajian Hashim et al. (2001), Nurhajati (2004), dan O'Regan et al. (2008) juga menemukan bahwa strategi bisnis yang diformulasikan dengan tepat, pengimplementasiannya mampu meningkatkan kinerja usaha. Lain halnya hasil kajian dari Edelman et al. (2002) bahwa strategi yang berbasis profil-profil sumber daya mampu menjelaskan kinerja pada perusahaan kecil. Selain itu, Rivard et al. (2005) menambahkan bahwa dukungan teknologi informasi (IT) terhadap strategi berperanan penting dalam meningkatkan kinerja perusahaan. Dengan demikian, dirumuskan hipotesis penelitian:

$\mathrm{H}_{2 \mathrm{~d}}$ : Penerapan strategi bersaing berpengaruh terhadap kinerja usaha.

\section{Pengaruh sumberdaya strategis terhadap kinerja usaha melalui mediasi strategi bersaing.}

Sumberdaya Strategis, Orientasi Kewirausahaan, dan Dinamika Lingkungan Terhadap Kinerja Usaha Melalui Mediasi Strategi Bersaing Perusahaan akan berpotensi memiliki keunggulan bersaing bila mampu menciptakan, memelihara dan mengembangkan sumber daya strategis yang digunakan sebagai basis pemilihan strategi bersaing, sehingga mampu berperan sebagai "strategic weapon" yang sesuai untuk manuver kompetisi pasar yang dihadapinya (Aaker, 2001). Hal ini mendorong pentingnya investasi untuk mengembangkan sumberdaya strategis agar sejalan dengan penerapan strategi dalam rangka penciptaan keunggulan bersaing serta menghasilkan kinerja superior (Barney et al., 2004; Carmeli, 2004 dan Grant, 2010).

Kesuksesan perusahaan dalam meningkatkan kinerja usaha tidak semata diperoleh dari penguasaan, pengelolaan dan pengembangan sumberdaya strategis yang dimiliki, akan tetapi ketepatan penerapan strategi bersaing yang berbasis sumberdaya strategis dimiliki relatif memberikan keuntungan yang lebih baik dalam 
jangka panjang. Pernyataan ini selaras dengan hasil kajian Edelman et al. (2002) bahwa sumber daya maupun strategi kurang mampu menjelaskan kinerja perusahaan secara parsial, namun strategi yang sesuai dengan profil sumber daya yang dimiliki mampu menjelaskan kinerja perusahaan.

Selain itu, Nurhajati (2004) juga menyampaikan bahwa faktor internal perusahaan berperan penting dalam penerapan strategi yang dapat menciptakan peningkatan kinerja usaha. Berdasarkan temuan tersebut, Nurhajati (2004) mengusulkan perlu adanya strategi tertentu untuk mengelola faktor-faktor internal tersebut sehingga lebih mampu berperan dalam meningkatkan kinerja usaha. Rivard et al. (2005) menemukan peran penting dukungan IT pada aset perusahaan terhadap kinerja usaha melalui mediasi dukungan IT pada strategi, karena memberikan efek positif terhadap kinerja pemasaran dan mengarah pada peningkatan profitabilitas. Dengan demikian, dapat dirumuskan hipotesis penelitian :

$\mathrm{H}_{3 \mathrm{a}}$ : Sumberdaya strategis berpengaruh positif terhadap kinerja usaha melalui mediasi strategi bersaing.

Pengaruh orientasi kewirausahaan terhadap kinerja usaha melalui mediasi strategi bersaing.

Dalam berbagai kajian, perusahaan yang menerapkan orientasi kewirausahaan yang dicerminkan pada pelaksanaan keinovasian, pengambilan resiko dan proaktivitas dalam aktivitas usaha mampu menghasilkan peningkatan kinerja (Avlonitis dan Salovou, 2007; Ferreira dan Azevedo, 2007; Yang, 2007). Namun, perusahaan yang berorientasi wirausaha berpotensi menghasilkan variasi kinerja yang lebih menguntungkan dalam jangka panjang, bila mampu mengidentifikasi dan memanfaatkan peluang dari lingkungan bisnis melalui penerapan strategistrateginya (Dollinger, 2002; Covin et al., 2006). Selain itu, orientasi kewirausahaan mampu membentuk fenomena organisasi yang mencerminkan kemampuan manajerial dengan menggunakan insiatif proaktif dan agresif untuk mengubah pandangan dalam berkompetisi (AtuaheneGima dan Ko, 2001).

Perusahaan berpotensi memiliki keunggulan bersaing yang lebih baik dengan mengintegrasikan pada strategi bersaingnya sebagai wujud pengidentifikasian dan pemanfaatan peluang dari lingkungan bisnis yang dihadapi, sehingga konsekuensinya mampu meningkatkan variasi kinerja yang lebih menguntungkan dalam jangka panjang. Hal ini sesuai dengan temuan Covin et al. (2006) yang melaporkan bahwa perusahaan entrepreneurial cenderung melaksanakan proses strategis dalam menghadapi lingkungan persaingan yang ketat, sehingga mampu memperbaiki atau meningkatkan kinerja usahanya. Oleh karena itu, dapat dirumuskan hipotesis penelitian :

$\mathrm{H}_{3 \mathrm{~b}}$ : Orientasi kewirausahaan berpengaruh positif terhadap kinerja usaha melalui mediasi strategi bersaing.

\section{Pengaruh dinamika lingkungan terhadap kinerja usaha melalui mediasi strategi bersaing.}

Dalam pendekatan kontinjensi, keselarasan antara strategi dengan lingkungan bisnis merupakan faktor penentu kelangsungan hidup dan kinerja perusahaan (Porter, 1996; O'Regan et al., 2008). Perusahaan yang mampu menyelaraskan strategi atau perusahaan menunjukkan tingkat adaptivitas dan fleksibilitas yang tinggi dengan lingkungan bisnisnya serta memperlihatkan kinerja yang lebih baik dibandingkan dengan perusahaan yang kurang berhasil menyelaraskan strategi dengan lingkungan bisnisnya (Anand dan Ward, 2004). Selain itu, penelitian-penelitian empiris yang telah membuktikan peran penting strategi sebagai elemen penyebab signifikannya hubungan lingkungan bisnis dengan kinerja perusahaan (Hashim et al., 2001; Rivard et al., 2006). 
Berdasarkan paparan di atas, kesuksesan perusahaan tergantung pada kemampuan memantau dan beradaptasi terhadap perubahan lingkungan bisnis yang dihadapi. Perusahaan dapat efektif dalam menjalankan usahanya apabila mampu mendesain struktur usaha yang sesuai dengan lingkungan bisnis yang dihadapi. Hal ini menegaskan peran penting kesesuaian penerapan strategi dengan lingkungan bisnis untuk mencapai hasil yang efektif bagi perusahaan.

Perusahaan akan berupaya untuk memperoleh posisi bersaing yang baik melalui pengamatan secara cermat dan mengelola kedinamisan dari lingkungan bisnisnya (Tan dan Tan, 2005). Dinamika lingkungan didefinisikan sebagai lingkungan eksternal yang berubah cepat dan bersifat diskontinyu, sehingga menimbulkan peningkatan ketidakpastian lingkungan dan intensitas persaingan yang tinggi. Agar tercipta efektifitas perusahaan, perlu mendesain strategi bersaing yang adaptif terhadap dinamika lingkungan yang dihadapi (Spanos, 2001). Sebagai wujud responsivitas strategi bersaing dengan lingkungan yang dinamis, perusahaan mampu memperoleh posisi bersaing yang unggul serta mengarah pada peningkatan kinerja usaha. Berdasarkan penjelasan tersebut, dapat diajukan hipotesis penelitian :

$\mathrm{H}_{3 \mathrm{c}}$ : Dinamika lingkungan berpengaruh positif terhadap kinerja usaha melalui mediasi strategi bersaing.

Berdasarkan rumusan hipotesis peneliti an di atas, dapat disusun model empiris dalam penelitian ini seperti tersaji pada Gambar 1.

\section{METODE PENELITIAN}

Penelitian ini merupakan penelitian survey yang bertujuan untuk menguji hipotesis dan menjelaskan peran sumber daya strategis, orientasi kewirausahaan, dan dinamika lingkungan terhadap strategi bersaing dan kinerja usaha. Adapun populasi dalam penelitian ini adalah selu- ruh UKM yang menghasilkan komoditas ekspor dan tercatat dalam Daftar Eksportir Daerah Bali tahun 2009 yang dipublikasikan oleh Dinas Perindustrian dan Perdagangan Provinsi Bali. UKM tersebut tersebar pada beberapa Kabupaten/Kota di Bali dengan jumlah sebanyak 308 unit usaha. Melalui pendekatan statistik dari Yamane (Ferdinand, 2006), jumlah sampel penelitian ini ditentukan sebanyak 174 unit.

Penentuan sampel menggunakan metode disproportionate sampling dengan alokasi pada jenis komoditas yang sesuai dengan frame populasi, serta pemilik/pengelola UKM ditentukan sebagai responden. Penelitian ini di lakukan pada usaha kecil dan menengah di Bali.

Terdapat 5 (lima) variabel yang digunakan dalam penelitian ini, antara lain sumber daya strategis $\left(X_{1}\right)$, orientasi kewirausahaan $\left(X_{2}\right)$, dan dinamika lingkungan $\left(X_{3}\right)$ merupakan variabel eksogen (bebas), serta strategi bersaing $\left(\mathrm{Y}_{1}\right)$ dan kinerja usaha $\left(\mathrm{Y}_{2}\right)$ ditentukan sebagai variabel endogennya (terikat). Khusus untuk variabel strategi bersaing $\left(Y_{1}\right)$, selain sebagai variabel endogen juga sebagai variabel antara (intervene) dalam model penelitian ini. Variabel-variabel yang telah disampaikan merupakan variabel laten (unobserved) yang diukur dari beberapa indikator. Tiap indikator terdiri atas beberapa item yang dijabarkan lebih lanjut dalam butir/item pertanyaan dalam instrumen penelitian sebagai variabel terobservasi.

Operasionalisasi variabel sumber daya strategis mengacu pada Dollinger (2002) dan Grant (2010) dengan menggunakan 6 indikator, yaitu: ketersediaan sumber daya fisik, pencapaian sumber daya reputasi, pengelolaan sumber daya organisasi, sumberdaya keuangan, sumberdaya manusia, dan penguasaan sumberdaya teknologi. Responden diminta untuk menanggapi tiap item yang berskala Likert 5 titik untuk menuntun seberapa baik penguasaan sumber daya strategis. 



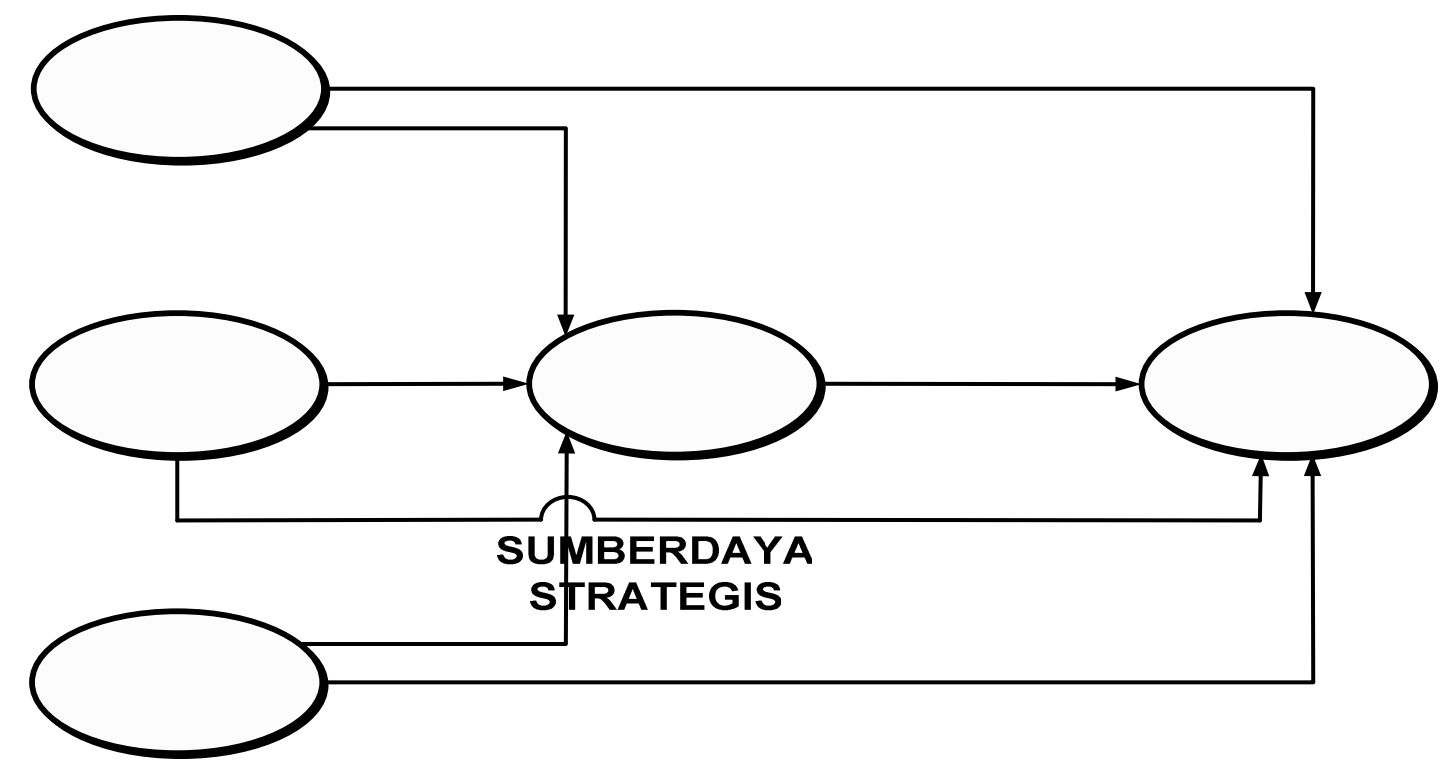

Gambar 1

Model Penelitian Empiris

Pada orientasi kewirausahaan $\left(\mathrm{X}_{2}\right)$, operasionalisasi mengompilasi instrumen dari Ferreira dan Azevedo (2007) dengan menggunakan 3 indikatokivaity AS inovasi, berani mengambil risi R proaktif. Responden diminta untuk mem berikan jawaban pada masing-masing item yang berskala Likert 5 titik untuk menuntun seberapa baik pelaksanaan orientasi kewirausahaan. Selanjut nya, variabel dinamika lingkungan $\left(X_{3}\right)$ mengompilasi instrumen yang dikembangkan Hashim et al. (2001) dan Rivard et al. (2005) dengan menggunakan indikator ketidakpastian lingkungan dan intensitas persaingan. Responden diminta memberikan tanggapan pada tiap i WMNAMKA program AMOS (Analysis of Moment berskala Likert 5 titik untuk mbilgk (GKkNGANructure) untuk menguji model empiris seberapa tinggi dan rendahnya dinamika lingkungan yang dihadap.

Variabel strategi bersaing $\left(\mathrm{Y}_{1}\right)$ mengacu pada strategi generik Porter's, yaitu: penerapan strategi kepemimpinan biaya, strategi diferensiasi, dan strategi fokus. Selanjutnya, pengukuran masingmasing indikator mengompilasi ukuran dari Hashim et al. (2001) dan Suci (2008). $\left(Y^{2}\right)$ mengadaptasi ukuran dari Camison
Responden diminta tanggapannya pada masing-masing item berskala 5 titik yang mengarah seberapa baik penerapan strategi bersaing. Stathlat, kinerja usaha dalam Sanchez dan Marin (2005) dengan menggunakan 3 indikator, yaitu: profitabilitas, produktivitas, dan pasar. Responden diminta untuk menanggapi tiap item berskala Likert 5 titik yang menuntun seberapa baik pencapaian kinerja usaha dalam 3 tahun terakhir.

Data yang diperoleh dari hasil distribusi kuesioner, selanjutnya dianalisi\$1 $\mathbf{c}(+)$ menggunakan Structural Equation Modeling (SEM) yang diaplikasikan melalui dan hipotesis dalam penelitian ini.

\section{ANALISIS DAN PEMBAHASAN}

Hasil pengujian hipotesis yang tersaji dalam Tabel 1 dan Gambar 2 menunjukkan bahwa sumberdaya strategis $\left(X_{1}\right)$ memiliki pengaruh positif dan signifikan terhadap strategi bersaing $\left(\mathrm{Y}_{1}\right)$ dengan koefisien jalur sebesar 0.314 dan probabilitas $(\mathrm{p})=0.000(\mathrm{p}<0.05)$. Hasil
STRATEGI BERSAING 
ini diartikan, semakin kuat penguasaan atau pengendalian sumberdaya strategis, maka penerapan strategi bersaing menjadi semakin tepat. Dengan demikian, hipotesis 1a (H1a) dapat dibuktikan.

Selain itu, ditemukan orientasi kewirausahaan $\left(X_{2}\right)$ ber pengaruh positif dan signifikan terhadap strategi bersaing $\left(\mathrm{Y}_{1}\right)$ dengan koefisien jalur sebesar 0.476 dan signifikansi $(p)=0.000(p<0.05)$.

Hasil ini dapat dimaknai bahwa semakin meningkat pelaksanaan orientasi kewirausahaan maka semakin tepat penerapan strategi bersaing, sehingga dinyatakan hipotesis $1 \mathrm{~b}$ (H1b) gagal ditolak. Dinamika lingkungan $\left(X_{3}\right)$ ditemukan berpengaruh positif dan signifikan terhadap strategi bersaing $\left(\mathrm{Y}_{1}\right)$ dengan koefisien jalur sebesar 0.312 pada signifikansi $(p)=0.000(p<0.05)$. Hasil ini mengindikasikan bahwa peningkatan dinamika lingkungan yang dihadapi mendorong peningkatan penyesuaian strategi bersaing, sehingga dinyatakan hipotesis 1c (H1c) dapat diterima. Informasi lain, hasil uji hipotesis dapat membuktikan bahwa sumber daya strategis $\left(X_{1}\right)$ berpengaruh positif dan signifikan terhadap kinerja usaha $\left(\mathrm{Y}_{2}\right)$ dengan koefisien jalur sebesar 0.140 dan probabilitas $(p)=0.029(p<0.05)$. Ini memberikan arti, sumber daya strategis yang semakin kuat mampu meningkatkan kinerja usaha, sehingga hipotesis 2a (H2a) terbukti kebenarannya.

Orientasi kewirausahaan $\left(X_{2}\right)$ tidak berpengaruh terhadap kinerja usaha $\left(\mathrm{Y}_{2}\right)$ dengan koefisien jalur sebesar 0.120 pada signifikansi $(p)=0.110(p>0.05)$. Hasil ini memberikan indikasi, peningkatan orientasi kewirausahaan belum tentu meningkatkan secara langsung kinerja usaha. Jadi, hipotesis $2 b(\mathrm{H} 2 b)$ gagal diterima. Dapat dibuktikan, dinamika lingkungan $\left(X_{3}\right)$ berpengaruh negatif dan signifikan terhadap kinerja usaha $\left(\mathrm{Y}_{2}\right)$ dengan koefisien jalur sebesar -0.161 dan signifikansi $(p)=0.011(p<0.05)$. Hasil ini memberikan makna peningkatan dinamika lingkungan mampu menghambat atau menurunkan kinerja usaha, sehingga hipotesis 2c (H2c) tidak ditolak.

Strategi bersaing $\left(\mathrm{Y}_{1}\right)$ berpengaruh positif dan signifikan terhadap kinerja usaha $\left(\mathrm{Y}_{2}\right)$ dengan koefisien jalur sebesar 0.837 dan probabilitas $(\mathrm{p})=0.000(\mathrm{p}<$ $0.05)$. Hasil ini dipahami, makin meningkat penerapan strategi bersaing mampu meningkatkan pencapaian kinerja usaha. Dengan demikian, hipotesis 2d (H2d) terbukti kebenarannya.

Pada pengaruh tak langsung, sumberdaya strategis $\left(X_{1}\right)$ terhadap kinerja usaha $\left(Y_{2}\right)$ melalui mediasi strategi bersaing $\left(Y_{1}\right)$ ditemukan memiliki efek positif dan signifikan dengan koefisien jalur (indirect effect) sebesar 0.263. Hasil ini memberikan makna bahwa sumber daya strategis yang semakin efektif sebagai basis strategi bersaing mampu meningkatkan kinerja usaha, sehingga hipotesis 3a (H3a) terbukti kebenarannya. Namun demikian, strategi bersaing bukan sebagai mediator kunci pada efek tak langsung sumber daya strategis terhadap kinerja usaha, karena strategi bersaing memediasi secara parsial (partial mediation).

Hasil kajian lebih lanjut, koefisien jalur pada efek tak langsung sumberdaya strategis terhadap kinerja usaha melalui mediasi strategi bersaing ditemukan lebih besar (0.263) dibandingkan koefisien jalur efek langsungnya (0.140) dengan total efeksebesar 0.403 . Temuan ini memberikan gambaran bahwa sumberdaya strategis yang digunakan sebagai basis strategi bersaing mampu memberikan dampak yang lebih besar terhadap pencapaian kinerja usaha dibandingkan dampak sumber daya strategis secara langsung.

Strategi bersaing $\left(\mathrm{Y}_{1}\right)$ terbukti memediasi secara positif dan signifikan pada pengaruh tak langsung orientasi kewirausahaan $\left(X_{2}\right)$ terhadap kinerja usaha $\left(\mathrm{Y}_{2}\right)$ dengan koefisien jalur (indirect effect) sebesar 0.398. Hasil ini 
memberikan arti bahwa pelaksanaan orientasi kewirausahaan yang dijadikan basis penerapan strategi bersaing mampu meningkatkan kinerja usaha, sehingga hipotesis $3 \mathrm{~b}(\mathrm{H} 3 \mathrm{~b})$ dapat diterima. Selain itu, strategi bersaing ditemukan sebagai mediator kunci pada efek tak langsung ini, karena memediasi secara sempurna (complete mediation). Apabila dicermati dari total efeknya, pelaksanaan orientasi kewirausahaan merupakan instrumen paling strategis dalam penyusunan strategi bersaing dibandingkan penguasaan sumber daya strategis, sehingga implementasi strategi bersaing menjadi semakin tepat dan mampu menghasilkan kinerja usaha yang lebih besar bagi perusahaan.

Dinamika lingkungan $\left(X_{3}\right)$ terhadap kinerja usaha $\left(\mathrm{Y}_{2}\right)$ melalui mediasi strategi bersaing $\left(\mathrm{Y}_{1}\right)$ memiliki efek tak langsung yang positif dan signifikan dengan koefisien jalur sebesar 0.261. Hasil ini memberikan makna bahwa penyesuaian strategi bersaing terhadap dinamika lingkungan yang dihadapi mampu meningkatkan kinerja usaha, sehingga hipotesis 3c (H3c) gagal untuk ditolak. Namun, strategi bersaing bukan sebagai mediator kunci pada efek tak langsung tersebut, karena strategi bersaing memediasi secara parsial (partial mediation).

Dalam kajian efek langsung, tak langsung, dan total pada hubungan dinamika lingkungan - strategi bersaing - kinerja usaha memberikan petunjuk bahwa dinamika lingkungan yang dihadapi secara langsung dapat menghambat pencapaian kinerja usaha. Oleh karena itu, penting bagi perusahaan untuk menerapkan strategi bersaing untuk menyelaraskan dinamika lingkungan yang dihadapi, karena kesesuaian strategi bersaing dengan dinamika lingkungan mampu memperbaiki atau meningkatkan kinerja usaha.

Proses transformasi melalui pengelolaan perusahaan berbasis sumber daya merupakan upaya-upaya strategis yang perlu ditempuh UKM untuk meraih keunggulan kompetitif terkait dengan perubahan-perubahan dramatis dari ling kungan bisnis yang dihadapi. Dengan penguasaan sumber daya strategis yang kuat, baik sumber daya fisik, sumber daya reputasi, sumber daya organisasi, sumber daya keuangan, sumber daya manusia, dan sumber daya teknologi sebagai kompetensi inti (Dollinger, 2002; Grant, 2010), UKM akan dapat memperbaiki atau memperkuat daya saingnya untuk berkompetisi.

Namun demikian, sumberdaya organisasi dan manusia merupakan sumber keunggulan kompetitif yang utama karena pengelolaan sumber keunggulan lain sangat bergantung pada kedua sumberdaya tersebut. Keterlibatan sumberdaya organisasi dan manusia sangat menentukan kesuksesan proses perubahan dari UKM, karena semakin baik tata laksana organisasi dan didukung kualitas sumber daya manusia maka pengendalian sumber daya strategis menjadi semakin kuat. Mengacu pada RBV of the firm, perusahaan yang mampu menguasai dan menggenerasi sumber daya sebagai kompetensi inti untuk dijadikan basis strategi merupakan sumber keunggulan perusahaan dalam berkompetisi, serta mengarahkan perusahaan untuk mencapai kinerja yang unggul (Barney, 2001; Barney et al., 2004).

Dalam RBV, orientasi kewirausahaan dianggap sebagai kapabilitas tambahan yang dapat memberikan keragaman dan nilai tambah bagi perusahaan (Ferreira \& Azevedo, 2007) atau kapabilitas organisasi yang menunjukkan proses kewirausahaan dan bagaimana aktivitas usaha mampu dijalankan (Foss et al., 2008; Hermann et al., 2008). Hasil penelitian telah membuktikan orientasi kewirausahaan sebagai instrumen penting dalam penerapan strategi bersaing, namun tidak mampu menjelaskan kinerja usaha secara langsung. 
Tabel 1

Hasil Pengujian Hipotesis

\begin{tabular}{|c|c|c|c|c|c|}
\hline \multirow[t]{2}{*}{ Hubungan Variabel } & \multicolumn{2}{|c|}{ Direct Effect } & \multirow{2}{*}{$\begin{array}{c}\text { Indirect } \\
\text { Effect }\end{array}$} & \multirow{2}{*}{$\begin{array}{l}\text { Total } \\
\text { Effect }\end{array}$} & \multirow[t]{2}{*}{ Keputusan } \\
\hline & Koef. & P-Value & & & \\
\hline $\begin{array}{l}\text { Sumber Daya Strategis }\left(\mathrm{X}_{1}\right) \rightarrow \\
\text { Strategi Bersaing }\left(\mathrm{Y}_{1}\right)\end{array}$ & 0.314 & 0.000 & - & 0.314 & H1a diterima \\
\hline $\begin{array}{l}\text { Orientasi Kewirausahaan }\left(\mathrm{X}_{2}\right) \rightarrow \\
\text { Strategi Bersaing }\left(\mathrm{Y}_{1}\right)\end{array}$ & 0.476 & 0.000 & - & 0.476 & $\mathrm{H} 1 \mathrm{~b}$ diterima \\
\hline $\begin{array}{l}\text { Dinamika Lingkungan }\left(\mathrm{X}_{3}\right) \rightarrow \\
\text { Strategi Bersaing }\left(\mathrm{Y}_{1}\right)\end{array}$ & 0.312 & 0.000 & - & 0.312 & H1c diterima \\
\hline $\begin{array}{l}\text { Sumber Daya Strategis }\left(\mathrm{X}_{1}\right) \rightarrow \\
\text { Kinerja Usaha }\left(\mathrm{Y}_{2}\right)\end{array}$ & 0.140 & 0.029 & 0.263 & 0.403 & H2a diterima \\
\hline $\begin{array}{l}\text { Orientasi Kewirausahaan }\left(\mathrm{X}_{2}\right) \rightarrow \\
\text { Kinerja Usaha }\left(\mathrm{Y}_{2}\right)\end{array}$ & 0.120 & 0.110 & 0.398 & 0.518 & H2b ditolak \\
\hline $\begin{array}{l}\text { Dinamika Lingkungan }\left(\mathrm{X}_{3}\right) \rightarrow \\
\text { Kinerja Usaha }\left(\mathrm{Y}_{2}\right)\end{array}$ & -0.161 & 0.011 & 0.261 & 0.100 & $\mathrm{H} 2 \mathrm{c}$ diterima \\
\hline $\begin{array}{l}\text { Strategi Bersaing }\left(\mathrm{Y}_{1}\right) \rightarrow \\
\text { Kinerja Usaha }\left(\mathrm{Y}_{2}\right)\end{array}$ & 0.837 & 0.000 & - & 0.837 & $\mathrm{H} 2 \mathrm{~d}$ diterima \\
\hline
\end{tabular}

Pemeriksaan Strategi Bersaing $\left(\mathrm{Y}_{1}\right)$ sebagai Variabel Mediasi : Model Tanpa Variabel Intervene (Mediasi)

\begin{tabular}{lccc}
\hline \hline \multicolumn{1}{c}{ Hubungan Variabel } & Koef. & P-Value & Keputusan \\
\hline Sumber Daya Strategis $\left(\mathrm{X}_{1}\right) \rightarrow$ & 0.400 & 0.000 & H3a diterima \\
Kinerja Usaha $\left(\mathrm{Y}_{2}\right)$ & & $($ Signifikan) & Partial Mediation \\
$\begin{array}{l}\text { Orientasi Kewirausahaan }\left(\mathrm{X}_{2}\right) \rightarrow \\
\text { Kinerja Usaha }\left(\mathrm{Y}_{2}\right)\end{array}$ & 0.530 & 0.000 & H3b diterima \\
$\begin{array}{l}\text { Dinamika Lingkungan }\left(\mathrm{X}_{3}\right) \rightarrow \\
\text { Kinerja Usaha }\left(\mathrm{Y}_{2}\right)\end{array}$ & 0.103 & $($ Signifikan) & Complete Mediation \\
\hline
\end{tabular}

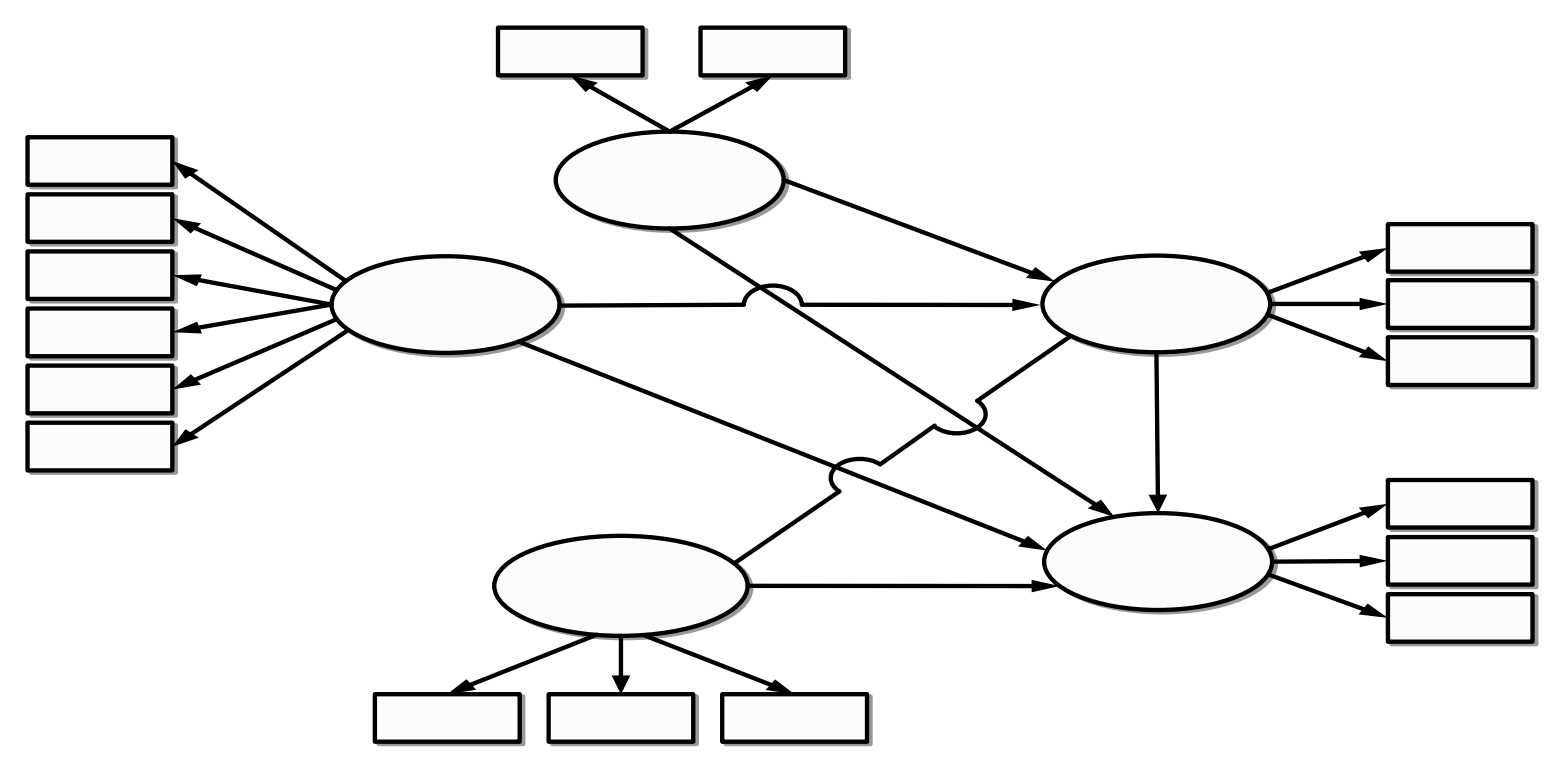

Gambar 2

Diagram Jalur Hasil Uji Hipotesis 
Temuan ini menunjukkan bahwa UKM mampu menghasilkan posisi kompetitif yang baik, apabila orientasi kewirausahaan yang dilaksanakan dengan keinovasian, sikap proaktif dan keberanian mengambil risiko terintegrasi dengan sumberdaya strategis untuk dijadikan landasan strategi bersaing. Hal ini dipahami, UKM yang berorientasi wirausaha dalam aktivitas usahanya mampu menggerakkan sumberdaya strategis secara efektif dan efisien guna mengidentifikasi peluang dan tantangan dari dinamika lingkungan yang dihadapi melalui proses perencanaan strategi.

Dalam proses tersebut, strategi bersaing yang dipilih UKM dapat diterapkan dengan tepat untuk memanfaatkan dan mengekploitasi peluang yang tersedia dalam dinamika lingkungannya, sehingga variasi kinerja usaha yang lebih menguntungkan dapat terwujud. Temuan penting ini memperkuat konsepsi Dollinger (2002) dan Covin et al. (2006) bahwa perusahaan yang berorientasi wirausaha (entrepreneurial) berpotensi menghasilkan variasivariasi kinerja yang lebih menguntungkan dalam jangka panjang dengan mengidentifikasi dan memanfaatkan peluang yang ada dalam lingkungan bisnisnya, selanjutnya dikembangkan menjadi keunggulan bersaing melalui penerapan strategistrategi.

Penelitian ini telah membuktikan dinamika lingkungan mampu menjelaskan kinerja usaha, baik secara langsung maupun melalui mediasi strategi bersaing. Apabila dicermati lebih lanjut, dinamika lingkungan berpengaruh negatif secara langsung terhadap kinerja usaha, namun memberikan pengaruh positif melalui mediasi strategi bersaing.

Hasil ini dapat dipahami bahwa dinamika lingkungan yang mencerminkan tingginya ketidakpastian lingkungan dan intensitas persaingan dapat memberikan dampak negatif atau menghambat pencapaian kinerja usaha.
Namun tidak sama halnya melalui penyelarasan atau penyesuaian strategi bersaing, kinerja usaha dapat ditingkatkan.

Hasil konfirmasi penelitian ini dengan penelitian-penelitan sebelumnya, diperoleh suatu informasi penting bahwa peluang dan tantangan dari dinamika lingkungan yang dihadapi mampu diidentifikasi dan dimanfaatkan melalui proses perumusan strategi bersaing, sehingga strategi bersaing dapat dilaksanakan dengan tepat dan menjurus pada peningkatan kinerja usaha. Dengan demikian, temuan ini dapat membuktikan konsep kontingensi (contingency) pada hubungan environment - strategy performance dari Anand dan Ward (2004); Hashim et al. (2001); dan Rivard et al. (2006) bahwa perusahaan yang mampu menyelaraskan strategi atau menunjukkan tingkat kesesuaian yang tinggi dengan lingkungan bisnisnya, sehingga mampu menghasilkan kinerja usaha yang lebih baik dibandingkan dengan perusahaan yang kurang berhasil menyelaraskan strategi dengan lingkungan bisnisnya.

Informasi penting lainnya yang dapat disampaikan dari hasil penelitian ini adalah peran strategi bersaing sebagai mediator kunci dalam integrasi sumber daya strategis, orientasi kewirausahaan, dan dinamika lingkungan, sehingga kesuksesan kinerja usaha dapat diwujudkan.

Ini mengindikasikan strategi bersaing merupakan kapabilitas strategis yang mampu menyesuaikan (fit) sumber daya strategis dan orientasi kewirausahaan dengan dinamika lingkungan yang dihadapi, sehingga kinerja usaha menjadi semakin meningkat.

Secara spesifik, hasil penelitian ini menginformasikan bahwa pengintegrasian sumberdaya organisasi dan keinovasian sebagai dasar implementasi strategi kepemimpinan biaya dapat menyelaraskan ketidakpastian lingkungan bisnis yang dihadapi UKM, sehingga menghasilkan peningkatan profitabilitas usaha. 


\section{SIMPULAN DAN SARAN \\ Simpulan}

Sumberdaya strategis, orientasi kewirausahaan, dan dinamika lingkungan merupakan landasan penting untuk menerapkan strategi bersaing dengan tepat. Kunci sukses dalam mencapai kinerja usaha ditentukan oleh sumber daya strategis dan strategi bersaing secara langsung, serta efek tak langsung sumber daya strategis, orientasi kewirausahaan, dan dinamika lingkungan melalui mediasi strategi bersaing. Hasil menarik dari penelitian ini adalah orientasi kewirausahaan terbukti bukan determinan langsung dari kinerja usaha, melainkan sebagai kapabilitas penting dalam penerapan strategi bersaing untuk menghasilkan variasi kinerja usaha yang lebih besar. Selain itu, strategi bersaing ditemukan sebagai mediator kunci yang mampu menyelaraskan sumberdaya strategis dan orientasi kewirausahaan dengan dinamika lingkungan yang dihadapi, sehingga kinerja usaha menjadi semakin meningkat.

Temuan penelitian secara keseluruhan mengindikasikan bahwa kombinasi sumberdaya strategis dan orientasi kewirausahaan merupakan instrumen strategis yang mendasari UKM untuk menerapkan strategi bersaing, sehingga mampu memperbaiki atau meningkatkan posisi kompetitifnya. Posisi kompetitif yang lebih baik diperoleh UKM, karena mampu menyelaraskan dinamika lingkungan bisnis yang dihadapi, dan menghantarkan UKM untuk meraih peningkatan kinerja usaha. Apabila UKM tidak menerapkan strategi bersaing yang dilandasi pengintegrasian sumber daya strategis dan orientasi kewirausahaan, maka dinamika lingkungan yang dihadapi dapat menghambat atau menurunkan pencapaian kinerja usaha.

\section{Saran}

Sumberdaya organisasi yang paling penting peranannya bagi UKM untuk memperkuat penguasaan sumber daya strategis. Oleh karena itu, sumber daya organisasi dalam bentuk kemampuan menjalankan usaha dengan efektif, kemampuan menyusun laporan kerja, dan kemampuan menyusun rencana usaha betul-betul perlu mendapat perhatian bagi pengelola UKM untuk meningkatkan pengimplementasian strategi kepemimpinan biaya (memperoleh harga bahan baku lebih murah, biaya proses produksi yang lebih efisien, biaya distribusi produk yang lebih efisien, dan harga produk yang lebih murah dibandingkan pesaing) yang akan meningkatkan profitabilitas usaha, baik peningkatan keuntungan, modal, dan aset usaha.

Keinovasian sangat berperan penting dalam orientasi kewirausahaan. Hal ini memberi petunjuk bagi pengelola UKM untuk mengedepankan keinovasian dalam kegiatan usaha dengan mengutamakan pengembangan disain produk yang khas dengan didasari kearifan lokal dan budaya religius yang kuat, serta menghasilkan produk yang bervariasi dan diminati pelanggan. Melalui upaya tersebut, UKM mampu menggerakkan sumberdaya strategis yang dikuasai untuk mengimplementasikan strategi kepemimpinan biaya, sehingga nantinya dapat meningkatkan kinerja usaha, terutama profitabilitas.

Untuk menghasilkan bersaing yang tepat untuk berkompetisi, selain cocok dengan kombinasi sumber daya strategis dan orientasi kewirausahaan, UKM perlu menyelaraskan strateginya dengan dinamika lingkungan bisnis yang dihadapi. Ketidakpastian lingkungan yang sangat krusial dalam dinamika lingkungan yang dihadapi UKM dibandingkan intensitas persaingan. Oleh karena itu, ketidakpastian lingkungan dalam wujud banyaknya pendatang/perusahaan baru, tingginya ancaman produk pengganti dari pesaing, ketatnya kondisi persaingan, tingginya kemampuan pemasok dalam menentukan harga bahan baku, dan tingginya kemampuan pembeli dalam menentukan harga jual produk harus dicermati dan dianalisis secara serius dan seksama oleh para pengelola UKM, sehingga dapat di- 
selaraskan untuk menerapkan strategi kepemimpinan biaya yang akan meningkatkan profitabilitas.

Upaya strategis lainnya yang penting dilakukan para pengelola UKM adalah membangun kerja sama kemitraan dengan perusahaan lain sejenis. Terjalinnya kemitraan yang kuat mampu meningkatkan daya saing UKM dalam memenuhi permintaan pelanggan dan menghasilkan efisiensi biaya bisnis, dan pada akhirnya mampu meningkatkan profitabilitas.

Penelitian ini menggunakan metode persepsi dalam mengukur kinerja usaha, sehingga dapat menimbulkan bias dalam pengukurannya. Selain itu, responden yang berpartisipasi dalam penelitian ini bersumber pada satu responden dalam satu perusahaan berpotensi terjadi mono response bias yang cukup besar. Keterbatasan ini mengarahkan penelitian di masa yang akan datang untuk menggunakan multiple measure (ukuran riil dan persepsi) dalam pengukuran kinerja usaha, sehingga dapat mereduksi bias dengan metode persepsi. Selain itu juga, penelitian mendatang sebaiknya menggunakan lebih dari satu responden dalam suatu perusahaan untuk memperoleh informasi yang lebih bervariasi.

Penelitian ini kurang mempertimbankan ukuran-ukuran penting dalam indikator ketidakpastian lingkungan pada variabel dinamika lingkungan, seperti: inflasi dari kenaikan harga BBM, nilai tukar mata uang (Rupiah terhadap US Dollar), dan aspek legal. Keterbatasan ini tentunya berdampak rendahnya obyektifitas dari ketidakpastian lingkungan, mengingat ukuran-ukuran tersebut berkaitan erat dengan lingkungan bisnis yang dihadapi UKM dalam aktivitas-aktivitas ekspor. Terkait dengan keterbatasan ini, penelitian mendatang hendaknya melibatkan ukuran penting tersebut untuk memperoleh informasi yang lebih obyektif.

Penelitian ini dilaksanakan dalam waktu yang relatif singkat (cross-sectional) dan pada situasi ekonomi yang relatif stabil.
Keterbatasan ini tentunya berdampak rendahnya generalisasi penelitian, mengingat permasalahan UKM sangat kompleks dan dinamis dari waktu ke waktu. Apabila model diterapkan pada waktu dan kondisi ekonomi yang berbeda memungkinkan memperoleh hasil yang berbeda pula. Penelitian mendatang dapat mereplikasi model penelitian ini melalui pendekatan longitudinal (dari waktu ke waktu), atau diaplikasikan sektor usaha selain UKM, seperti: usaha besar atau industri-industri spesifik lainnya.

\section{DAFTAR PUSTAKA}

Aaker, D. A. 2001. Developing Business Strategies. $6^{\text {th }}$ ed. John Wiley \& Sons Inc. USA.

Ainuddin. A. R., P. W. Beamish, J. S. Hulland, dan M. J. Rouse. 2007. Resource Attributes and Firm Performance in International Joint Ventures. Journal of World Business. Elsevier 42: 47-60.

Alejandro, E., L. Sánchez-Peinado, dan E. Sánchez-Peinado, 2008. Moderating Influences on The Firm's Strategic Orientation-Performance Relationship. International Small Business Journal 26: 463-489.

Alvarez, S. A. dan L. W. Busenitz. 2001. The Entrepreneurship of Resource-Based Theory. Journal of Management 27: 755775.

Anand, G. dan P. T. Ward. 2004. Fit, Flexibility and Performance in Manufacturing: Coping with Dynamic Environments, Production and Operations Management 13(4): 369-385.

Anatan, L. dan L. Ellitan. 2009, Strategi Bersaing: Konsep, Riset, dan Instrumen. Alfabeta Bandung.

Atuahene-Gima, K. dan A. Ko. 2001. An Empirical Investigation of The Effect of Market Orientation and Entrepreneurship Orientation Alignment on Product Innovation. Organ Sci. 12(1): 54-74. 
Avlonitis, G. J. dan H. E. Salavou. 2007. Entrepreneurial Orientation of SMEs, Product Innovativeness, and Performance. Journal of Business Research 60: 566-575.

Barney, J. B. 2001. Gaining and Sustaining Competitive Advantage. Addison Westley Reading. Mass.

Barney, J. B., G. Ray, dan W. A. Muhanna. 2004. Capabilities, Business Processes, and Competitive Advantage: Choosing the Dependent Variable in Empirical Tests of The Resource-Based View. Strategic Management Journal 25: 23-37.

Carmeli, A. 2004. Assessing Core Intangible Resources. European Management Journal 22(1): 110-122.

Chmielewski, D. A. dan A. Paladino. 2007. Driving a Resource Orientation: Reviewing The Role of Resource and Capability Characteristics. Management Decision 45(3): 462-483.

Collis, D. dan C. Montgomery. 2004. Corporate Strategy : A Resource - Based Approach. $2^{\text {nd }}$ ed. Irwin McGraw-Hill Boston.

Covin, J. G., K. M. Green, dan D. P. Slevin. 2006. Strategic Process Effect on The Entrepreneurial Orientation-Sales Growth Rate Relationship. Entrepreneurship Theory and Practice 30(1): 5781.

Daniel, M. V. dan R. G. Rangel. 2007. Development of Internal Resources and Capabilities as Sources of Differentiation of SME Under Increased Global Competition: A Field Study in Mexico. Technological Forecasting and Social Change 74: 90-99.

DeSarbo, W. S., C. A. Benedetto, M. Song, dan S. Indrajit. 2005. Revisiting The Miles and Snow Strategic Frame-work: Uncovering Interrelationships Between Strategic Types. Capabilities, Environmental Uncertainty, and Firm Performance. Strategic Management Journal 6: 47-74.

DeSarbo, W. S., C. A. Benedetto, dan M. Song. 2007. Heterogenous Resource
Based View for Exploring Relationships Between Firm Performance and Capabilities. Journal of Modeling in Management 2(2): 103-130.

Dinas Perindustrian dan Perdagangan Propinsi Bali. 2008. Indag dalam Angka Tahun 2007. Bali.

Dollinger, M. J. 2002. Entrepreneurship: Strategies and Resources. $3^{\text {rd }}$ ed. Richard D Irwin Publishing. Boston.

Edelman, L. F., C. G. Brush, dan T. Manolova. 2002. The Mediating Role of Strategy on Small Firm Performance. Working Paper 2004-03.

Ferdinand, A. 2006. Metode Penelitian Manajemen: Pedoman Penelitian untuk Penulisan Skripsi, Tesis dan Disertasi Ilmu Manajemen. Edisi Kedua. Semarang. Badan Penerbit Universitas Diponegoro.

Ferreira, J. dan S. Azevedo. 2007. Entrepreneurial Orientation as A Main Resource and Capability on Small Firm's Growth, MPRA Paper, No. 5682, posted 09. November 2007.

Foss, N. J., P. G. Klein, Y. Y. Kor, dan J. T. Mahoney. 2008. Entrepreneurship, Subjectivism and Resource-Based View: Toward a New Synthesis. Strategic Entrepreneurship Journal 2: 73-94.

Grant, R. M. 2010. Contemporary Strategy Analysis. $7^{\text {th }}$ ed. John Wiley and Sons Ltd.

Green, K. M., J. G. Covin, dan D. P. Slevin. 2008. Exploring the Relationship Between Strategic Reactiveness and Entrepreneurial Orientation: The Role of Structure-Style Fit. Journal of Business Venturing 23: 356-383.

Hakim, A. 2007. Karakteristik Kewirausahaan, Lingkungan Bisnis dan Kapabilitas Organisasi: Pengaruhnya terhadap Strategi Bisnis dan Kinerja Usaha. Disertasi - Tidak Dipublikasikan. Program Pascasarjana Universitas Brawijaya. Malang.

Hashim, M. K., S. A. Wafa, dan Sulaiman. 2001. Testing Environment as Mediator Between Bussiness Strategy - Performance 
Relationship : A Study of Malaysian SMEs, $46^{\text {th }}$ ICSB World Conference, Jan 17-20 2001, Taipei, Taiwan.

Hermann, F., A. Kessler, dan M. Fink. 2010. Entrepreneurial Orientation and Business Performance: A Replication Study. Strategic Business Review 62: 175198.

Hitt, M. A., D. Ireland, dan R. E. Hoskisson. 2011. Strategic Management: Competitiveness and Globalization, $9^{\text {th }}$ ed. SouthWestern Cengage Learning Oklahoma.

Ireland, R. D., M. A. Hitt, S. M. Camp, dan D. L. Sexton. 2001. Integrating Entrepreneurship and Strategic Management Actions to Create Firm Wealth. Academy of Management Executive 15(1): 49-63.

Ireland, R. D., M. A. Hitt, dan D. G. Sirmon. 2003. A Model of Strategic Entrepreneurship: The Construct and It's Dimensions. Journal of Management 29: 963.

Ireland, R. D. dan J. W. Webb. 2007. Strategic Entrepreneurship: Creating Competitive Advantage Through Streams of Innovation. Business Horizons 50: 49-59.

Kaya, H. dan V. Agca. 2006. Entrepreneurial Orientation and Performance of Turkish Manufacturing FDI Firms: An Empirical Study http://www.uic. edu/cba/ies/2006papers. Diakses tanggal 4 Mei 2012.

Lee, D. Y. dan E. W. K. Tsang. 2001. The Effect of Entrepreneurial Personality, Background and Network Activities on Venture Growth. Journal of Management Studies 38(4): 583-602.

Miles, M. P., J. G. Covin, dan M. B. Heeley. 2000. The Relationship Between Environmental Dynamism and Small Firm Structure, Strategy, and Performance. Journal of Marketing Theory and Practice Spring: 63-74.

Nurhajati. 2004. Analisis Faktor-Faktor yang Mempengaruhi Kinerja dan Keunggulan Bersaing Usaha Kecil yang Berorientasi Expor di Jawa Timur.
Disertasi - Tidak Dipublikasikan. Program Pascasarjana Universitas Brawijaya. Malang.

O'Regan, N. S., A. Martin dan D. Gallear. 2008. Leaders, Loungers, Laggards. The Strategic-Planning-Environment Performance Relationship Revisited in Manufacturing SME. Journal of Manufacturing Technology Manage-ment 19(1): 6-21.

Porter, M. E. 1996. What is Strategy? Harvard Business Review 76(6): 61-77.

Rivard, S., L. Raymond, dan D. Verreault. 2006. Resource-Based View and Competitive Strategy: An Integrated Model of The Contribution of Information Technology to Firm Performance. Journal of Strategic Information Systems 15: 29-50.

Riyanti, B. P. D. 2003. Kewirausahaan dari Sudut Pandang Psikologi Kepribadian. Grasindo Jakarta.

Sanchez, A. A. dan G. S. Marin. 2005. Strategic Orientation, Management Characteristics, and Performance: A Study of Spanish SME's. Journal of Small Business Management 43(3): 287-306.

Scarborough, N. M. dan T. W. Zimmerer. 2008. Essential of Entrepreneurship and Small Business Management. Prentice Hall International Inc. New Jersey.

Spanos, Y. E. dan S. Lioukas. 2001. An Examination Into The Causal Logic of Rent Generation: Contrasting Porter's Competitive Strategy Framework and The Resource-Based Perspective, Strategic. Management Journal 22(10): 907-934.

Suci, R. P. 2008. Pengaruh Orientasi Kewirausahaan, Dinamika Lingkungan, Kemampuan Manajemen serta Strategi Bisnis Terhadap Kinerja: Studi pada Industri Kecil Menengah Bordir di Jawa Timur. Disertasi - Tidak Dipublikasikan, PPS UB, Malang.

Tan, J. dan D. Tan. 2005. Environment Strategy Co-Evolution and CoAlignment: A Staged Model of Chinese 
SOE's Under Transition. Strategic Management Journal 26: 141-157.

Vitale, R., J. Giglierano, dan M. Miles. 2003. Entrepreneurial Orientation, Market Orientation, and Performance in Established and Startup Firms http://www. uic.edu/cba/ ies/2003 papers. Diakses 5 Juli 2012.

Wiklund, J., dan D. Shepherd. 2005. Entrepreneurial Orientation and Small Business Performance: A Configurational Approach. Journal of Business Venturing 20: 71-91.

Yang, C. W. 2007. The Relationships Among Leadership Styles, Entrepreneurial Orientation, and Business Performance. Managing Global Transitions 6(3): 257275. 